\title{
Population structure and trap success of bandicota indica (bechstein, I800) in the four allocated study sites Magway region in Myanmar
}

\begin{abstract}
A total of Bandicota indica (324 rats) were trapped from four villages in four townships in Magway Region during June, 2016 to May, 2017. It is significant problem to farmers in agriculture and considered as the second most important pest after insects because it is the least controlled. The other rat species generally cause little crop damage. Trapping data revealed that the population abundance of rats changed over time in response to the availability of food resources. The peak population of B. indica in the rice fields occurred during the ripening, harvesting and booting stage of rice. The lowest number of bandicoot rat population was during the fallow and early growing stages. According to the monthly data, the maximum population of B. indica was found in October and minimum in April. Thus the population of B. indica needs to be regularly monitored in study area for reducing the damage of crops and to safeguard the yield.
\end{abstract}

Volume 4 Issue 4 - 2019

\author{
Aye Yu San,' Mie Mie Sein² \\ 'Department of Zoology, Magway University, Myanmar \\ 2Mawlamyine University, Myanmar
}

Correspondence: Aye Yu San, Assistant Lecturer, Department of Zoology, Magway University, Myanmar,

Email ayeyusan022@gmail.com

Received: July 19, 2019 | Published: August 02, 2019

Keywords: Bandicota indica, population structure, trap success, crop field, rats

\section{Introduction}

Small mammals are often considered as pests on agricultural land The damage they inflict can occur at all stages of crop development; by digging up newly planted seeds, cutting tillers, destroying roots, direct grazing or consuming developing grain as the crop matures and reducing seed regeneration. ${ }^{1}$ Rodents are a chronic agricultural problem in most areas of Lao PDR with sporadic outbreaks in upland agro-ecosystems. ${ }^{2}$ Several species of murine rodents occur in the ricefields of southern Asia. ${ }^{3}$ Rats are becoming a most serious pest of rice in Asia causing annual pre-harvest losses of about 5-10\%. In addition, to these losses, reports of $20 \%$ losses to grain post-harvest from rats are not unusual. ${ }^{4}$

The single most common rodent pest in rice field is Rattus argentiventer in Indonesia and Malaysia. In Bangladesh, the principal pest species are Bandicota indica and Bandicota bengalensis. ${ }^{5}$ The present study was conducted on the most common rodent species in rice fields Bandicota indica, in the allocated four study sites in Magway Region, the results of which is hoped to provide some information and understanding on the population of $B$. indica in some of Magway Region.

\section{The objectives of this research were:}

1. To assess the population structure of Bandicota indica in four allocated study sites in Magway Region

2. To determine the trap success of Bandicota indica in study area

\section{Materials and methods}

\section{Study area}

Four study sites were chose because the most of farmers cultivated the rice and legume alternately year round in these areas. This opportunity is provided the abundance of food for Bandicoot rats. Catch area of Murinae was about 4 ha in each site (Figure 1).

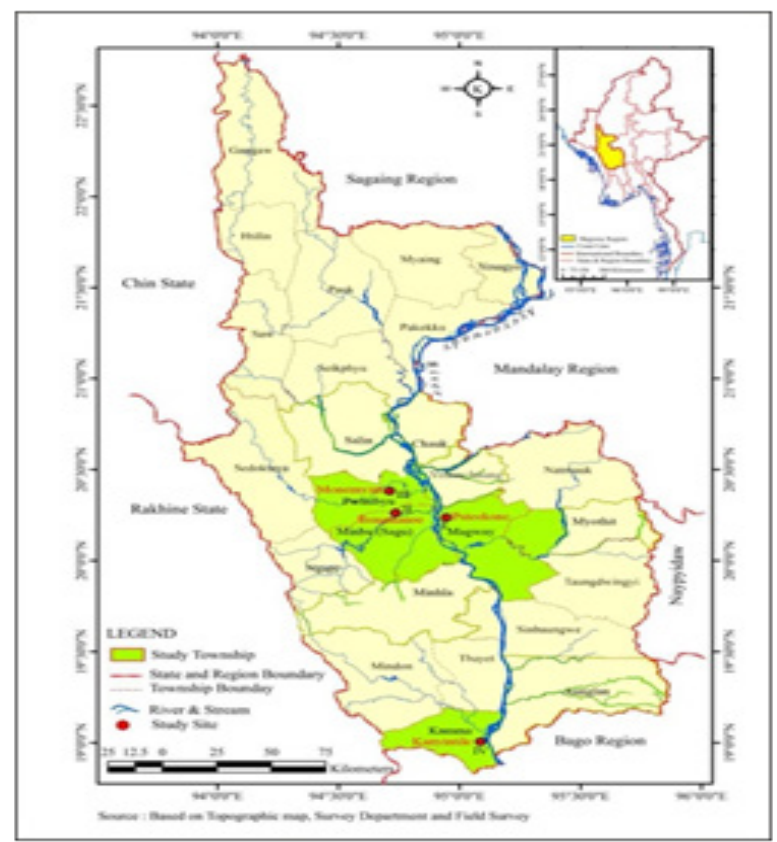

Figure I Map of Magway region.

Sites I: Puteekone village in Magway Township.

Site II: Bonemanoe village of Minbu (Sagu) Township.

Site III: Monemyint village of Pwintbyu Township.

Site IV: Kanyintile village of Kamma Township.

Study period: Between June, 2016 and May, 2017, rodent survey was conducted in Magway Region. 


\section{Collection of the samples}

Monthly trappings lasted for three consecutive nights per set in the four sampling locations. A total of 50 traps were placed around the study sites each night. The traps were set in the evening and collected the next morning at sun rise. Captured rats were recorded and identified individually, sexed, weight, length of tail, ear, hind foot (without claw) and head plus body were measured and recorded.

\section{Data analysis}

Trap success was calculated as the number of rodents captured divided by the total number of traps set, multiplied by 100 (Figure 1 ).

Trap success $=\frac{\text { The number of rodents captured }}{\text { The total number of traps set }} * 100$

\section{Results}

\section{Population Structure of Bandicota indica in four study sites}

The total 324 rats, 183 male rats and 141 female rats were recorded in study area. The highest number of $B$. indica was trapped in October (41rats) and the lowest number was trapped in April (10 rats). Among the four study Townships, the highest numbers of $B$. indica were found in Kamma Township (107 rats) followed by 90 rats in Minbu (Sagu) Township, 73 rats in Pwintbyu Township and 54 rats in Magway Township (Table 1). According to ANOVA test, there was not significantly difference in monthly population of Bandicota indica rats among the study sites. In present study, according to the frequency distribution of body weight, the highest frequency number of male (56 rats) were found in size class $(400-499 \mathrm{~g})$. The highest frequency number of female (49 rats) were also found in size class (400-499g) (Table 2). The mean body weight of male was $356.6 \pm$ $120.5 \mathrm{~g}$ and female was $368.6 \pm 116.4 \mathrm{~g}$.

The highest frequency number of head and body length were found in size class $175-199 \mathrm{~mm}$ in both male and female (Table 3). The lowest number in male was the size class $(125-149 \mathrm{~mm})$ and in female was $(100-124 \mathrm{~mm})$. The mean head and body length was $185.6 \pm 35.7 \mathrm{~mm}$ in male and $183.1 \pm 36.9 \mathrm{~mm}$ in female.

\section{Trap Success of Banticota indica in four study sites}

The highest trap success percentage revealed in Kamma (5.94\%) followed by Minbu (Sagu) (5\%), Pwintbyu (4.06\%) and Magway (3\%) for the 1800 trap-nights of sampling (Table 4).

Table I Monthly numbers of Bandicota indica recorded in four study sites during June, 2016 to May, 2017

\begin{tabular}{|c|c|c|c|c|c|c|c|c|c|c|c|c|c|}
\hline Site & $\begin{array}{l}\text { June } \\
(2016)\end{array}$ & $\begin{array}{l}\text { July } \\
(2016)\end{array}$ & $\begin{array}{l}\text { August } \\
(2016)\end{array}$ & $\begin{array}{l}\text { September } \\
(2016)\end{array}$ & $\begin{array}{l}\text { October } \\
(20 \mid 6)\end{array}$ & $\begin{array}{l}\text { November } \\
(2016)\end{array}$ & $\begin{array}{l}\text { December } \\
(2016)\end{array}$ & $\begin{array}{l}\text { January } \\
(2017)\end{array}$ & $\begin{array}{l}\text { February } \\
(20 \mid 7)\end{array}$ & $\begin{array}{l}\text { March } \\
(20 \mid 7)\end{array}$ & $\begin{array}{l}\text { April } \\
(20 \mid 7)\end{array}$ & $\begin{array}{l}\text { May } \\
(2017)\end{array}$ & Total \\
\hline Magway & 3 & 4 & 5 & 5 & 7 & 5 & 6 & 4 & 4 & 3 & 3 & 5 & 54 \\
\hline $\begin{array}{l}\text { Minbu } \\
\text { (Sagu) }\end{array}$ & 5 & 5 & 6 & 11 & 12 & 13 & 12 & 9 & 8 & 3 & 2 & 4 & 90 \\
\hline Pwintbyu & 6 & 7 & 7 & 7 & 8 & 8 & 9 & 6 & 7 & 3 & 2 & 3 & 73 \\
\hline Kamma & 7 & 5 & 7 & 13 & 14 & 14 & 12 & 11 & 12 & 4 & 3 & 5 & 107 \\
\hline Total & 21 & 21 & 25 & 36 & $4 I$ & 40 & 39 & 30 & 31 & 13 & 10 & 17 & 324 \\
\hline
\end{tabular}

Table 2 Frequency distribution of body weight of males and females Bandicota indica recorded from all study sites

\begin{tabular}{llll}
\hline Body weight $(\mathrm{g})$ & Male & Female & Total \\
\hline $100-199$ & 26 & 17 & 43 \\
$200-299$ & 29 & 18 & 47 \\
$300-399$ & 53 & 42 & 95 \\
$400-499$ & 56 & 49 & 105 \\
$500-599$ & 19 & 15 & 34 \\
Total & 183 & 141 & 324 \\
\hline
\end{tabular}

Table 3 Frequency distribution of head and body length of males and females Bandicota indica recorded in all study sites

\begin{tabular}{llll}
\hline Head and body length $(\mathbf{m m})$ & Male & Female & Total \\
\hline $100-124$ & 16 & 11 & 27 \\
$125-149$ & 12 & 16 & 28 \\
$150-174$ & 28 & 28 & 56 \\
$175-199$ & 68 & 38 & 106 \\
$200-224$ & 28 & 25 & 53 \\
$225-249$ & 31 & 23 & 54 \\
Total & 183 & 141 & 324 \\
\hline
\end{tabular}

Table 4 Number and percentages trap success of Bandicota indica in each site during June, 2016 to May, 2017

\begin{tabular}{lllll}
\hline Site & $\begin{array}{l}\text { Total number of } \\
\text { rats captured }\end{array}$ & $\begin{array}{l}\text { Captured } \\
\text { percentage (\%) }\end{array}$ & $\begin{array}{l}\text { Total number } \\
\text { of trap set }\end{array}$ & $\begin{array}{l}\text { Trapping } \\
\text { success (\%) }\end{array}$ \\
\hline Magway & 54 & 16.67 & 1800 & 3 \\
Minbu (Sagu) & 90 & 27.78 & 1800 & 5 \\
Pwintbyu & 73 & 22.53 & 1800 & 4.06 \\
Kamma & 107 & 33.02 & 1800 & 5.94 \\
Total & 324 & & & \\
\hline
\end{tabular}




\section{Discussion}

During the present study, four townships were allocated in Magway Region because these sites have various farms and orchards. Bandicota indica is one of the key pests in the rice fields and crop farms. The population of B. indica was the highest in October (41 rat) and the lowest in April (10 rat), due to the ripening of paddy during the month of October and the post-harvest was in April in study area. The rodent population density increased after the onset of short rains. This change can also be interpreted due to variations in food supply and plant cover. ${ }^{7}$

In present study, the mean body weight of female (368.6 \pm 16.4 g) was higher than mean body weight of male $(356.6 \pm 120.5 \mathrm{~g})$ Especially, body weight of female increased during the pregnant time. The higher frequency of rats were found in body weight size classes $(300-399 \mathrm{~g})$ and $(400-499 \mathrm{~g})$ in both sex. According to the population of rat, the male rats more frequently encountered than female. The relative excess of males may result from their greater activity and larger home range, which would tend to produce a higher probability of capture than that of the females. ${ }^{7}$ These finding are consistent with the results of the present study. The adult males were captured more frequently than adult females in all studied sites. Therefore, it indicated that were more dominant, were more active and tend to move farther than the adult females. The prevalence of pregnancy was related to body size of the female. It is indicated that the pregnant female of Bandicoot rat increased body size. ${ }^{8}$

The month of June and July are for ploughing and preparation for planting of rice. The actual planting of rice occurs in September and October. The booting and ripen time of rice occur in November and December. Since food sources of rats are abundant in study area thus gain in weight for female bandicoot rat. The differences in the timing of food availability may also affect growth patterns of rat population, which may alter their population structure in different environments. To increase food availability may occur, increased individual growth rates, resulting in more rapid maturation and higher abundance of adults, increased reproductive effort per adult. All responses are likely to lead to increase population densities.

In the present study, Kamma supported the largest rice field area than other study sites thus the rice are main crop plants in this area. The highest population densities of greater bandicoot rat were recorded in Kamma Township. Therefore highest trap success was observed in Kamma Township. The population status of greater bandicoot rat revealed to be very important in Magway Region in order to implement efficient management at the right time. The population and behavioral ecology of the rodents are important for outline efficient control measures to be implemented in safeguarding the crop yield. ${ }^{9,10}$

\section{Acknowledgements}

None.

\section{Conflicts of interest}

Author declares that there are no conflicts of interest.

\section{Funding}

None.

\section{References}

1. Ibrahim H. The role of migration in the distribution of the brown rat in the UK agricultural landscape. England: PhD Dissertation, University of Leicester.

2. Douangboupha B, Brown PR, Khamphoukeo K, et al. Population dynamic of rodent pest species in upland farming system of Lao PDR. Kasetsart J Nat Sci. 2009;43:125-131.

3. Thitipramote N, Suwanjarat J, Breed WG. Reproductive biology of the greater bandicoot rat Bandicota indica (Rodentia: Muridae) in the rice fields of southern Thalaid. Curr J Zool. 2009;55(1):48-55.

4. Singleton GR. Impact of Rodents on Rice Production in Asia. USA: IRRI Discussion Paper Series No. 43. International Rice Research Institute, Los Banos; 2003.

5. Islam Z, Morton RG, Jupp BP, et al. The effect of rat damage on deep water rice yield in Bangladesh. International Journal of Pest of Management. 1993;39(2):250-254.

6. Aplin KP, Brown PR, Jacob J, et al. Field method for rodent studies in Asia and the Indo-Pacific. Australian: Australian Centre for International Agricultural Research; 2003.

7. Florence TM. Rodent species and their seasonal variations in Arusha Northern Tanzania. Anzeiger fur Schadlingskunde, Pflanzenschutz, Umweltschutz. 1996;69(4):90-92.

8. Hussain I, Ahmad MM, Brooks J, et al. Body Size, Sex Ratio and Reproduction of Bandicota bengalensis in Northern Punjab, Pakistan Pakistan Zool. 1992;24(3):193-198.

9. Khairuddin NL, Raghazil R, Sah SAM, et al. The population size of the lesser Bandicoot (Bandicota bengalensis) in three market in Penang, Malaysia. Trop Life Sci Res. 2011;22(2):81-92.

10. Singleton GR, Petch DA. A review of the biology and management of rodent pests in Southeast Asia. Canberra: ACIRA Technical Reports No; 1994. 